\title{
Process of Social Transformation among women in India Nazhath Sara
}

University of Mysore, Department of studies in Socialogy, Manasagangothri, Mysore, Karnataka, India.

\section{ABSTRACT}

sara.nazhath@gmail.com

A woman is a human being she has a soul similar to that of a man. A "woman" defined as the "feminine component of the human species who, apart from serving as a vehicle for nurturing human life also equally contribute in social, economic and political development in society". The concept of social transformation have a similar definition as social change, many authors have used both terms interchangeably. Social change refers to fundamental changes in the social structure, patterns of culture and social behavior. "Change" means variations or a difference in anything observed over some period of time. Social change is very complex. Since society is a process not product. If it had been product then there would not have been changes. Processes are ongoing change therefore they bound to change. Society is changeful and dynamic. We can say that change is a law of society unchanging society is a myth. Hence, social change is important for society as well as women. In this paper attempt has been made to analyze social change taking place in India especially among Indian women.

\section{Indexing terms/Keywords}

Social Transformation, Social Change, Status of Women in India, Literacy in India, Female Population in India, Constitution of India.

\section{Academic Discipline And Sub-Disciplines}

Sociology

\section{SUBJECT CLASSIFICATION}

Social Transformation

\section{TYPE (METHOD/APPROACH)}

\section{Literary Analysis}

\section{Council for Innovative Research}

\section{Peer Review Research Publishing System}

\section{Journal: Journal of Social Sciences Research}

Vol. 8, No. 2

jssreditor.cir@gmail.com

www.jssronline.com 


\section{INTRODUCTION}

Social transformation is a philosophical, practical and strategic process, to effect revolutionary change within society. It is systematic approach applied to social change, which is comprehensive and progressive approach to social change. That is why social transformation is different from ordinary or conventional social change. When social transformation is applied, identity (way of seeing, thinking, reflecting on ourselves and others) will be altered, not only this but emotions, embodiments (relationship and connectedness to and within our bodies how we show up), actions, creativity and paradigm (overall perspective and mode of operating).

Social transformation is the process by which an individual alters the socially ascribed social status of their parents into socially achieved status for themselves.

The last quarter of the 20th Century was a period of rapid growth in transitional linkages and flows affecting all areas of human life: economy, politics, environment, culture, society and even interpersonal relations. These transitional linkages have also affected women, So we see more women representations in these fields, and the question arises that how far Muslim women has gone through these changes.

Social transformation is an accumulative process - that is a process in which insignificant changes accumulate quantitatively until they become significant enough to generate to qualitative changes in the entire society. As women education was considered as insignificant because of the quantitatively changes now importance is being given to women education as well.

Women in India have been in the process of transformation in past few decades. Earlier Indian women did not enjoy the social, economic, political and legal rights. It is only after the independence Indian women got all these rights through Indian constitution. Women in India have been in the process of transformation in past few decades. Earlier Indian women did not enjoy the social, economic, political and legal rights. It is only after the independence Indian women got all these rights through Indian constitution. The Constitution of India guarantees to all Indian women equality (Article 14), no discrimination by the State (Article 15(1)), equality of opportunity (Article 16), and equal pay for equal work (Article 39(d)). In addition, it allows special provisions to be made by the State in favor of women and children (Article 15(3), renounces practices derogatory to the dignity of women (Article 51(A) (e)), and also allows for provisions to be made by the State for securing just and humane conditions of work and for maternity relief. (Article 42)

On the other hand women in India continue to face discrimination and other social challenges and are often victims of abuse and violent crimes. As per the global poll conducted by Thomson Reuters, India is the "fourth most dangerous country" in the world for women and the worst country for women among the G20 countries.

According to 2011 census female population constitutes the $58,64,69,174(48 \%)$ of the total population and whereas male population is $62,37,24,248(52 \%)$ of the total population $1,0 \backslash, 1,93,422$.

In the state of Karnataka the total population as per 2011 census is $61,130,704$ and among them male $31,057,742(51 \%)$ and female $30,072,962(49 \%)$.

Mysore city in particular total population is $8,87,446(50.46 \%)$ of which male are $4,43,813(50.0)$ and female 4,43,633(49.98\%).

Women in India have been in the process of transformation in past few decades. Earlier Indian women did not enjoy the social, economic, political and legal rights. It is only after the independence Indian women got all these rights through Indian constitution. The Constitution of India guarantees to all Indian women equality (Article 14), no discrimination by the State (Article 15(1)), equality of opportunity (Article 16), and equal pay for equal work (Article 39(d)). In addition, it allows special provisions to be made by the State in favor of women and children (Article 15(3), renounces practices derogatory to the dignity of women (Article $51(\mathrm{~A})(\mathrm{e})$ ), and also allows for provisions to be made by the State for securing just and humane conditions of work and for maternity relief. (Article 42)

On the other hand women in India continue to face discrimination and other social challenges and are often victims of abuse and violent crimes. As per the global poll conducted by Thomson Reuters, India is the "fourth most dangerous country" in the world for women and the worst country for women among the G20 countries.

According to 2011 census female population constitutes the $58,64,69,174(48 \%)$ of the total population and whereas male population is $62,37,24,248(52 \%)$ of the total population $1,210,1,93,422$.

In the state of Karnataka the total population as per 2011 census is $61,130,704$ and among them male $31,057,742(51 \%)$ and female 30,072,962(49\%).

Mysore city in particular total population is $8,87,446(50.46 \%)$ of which male are $4,43,813(50.0)$ and female $4,43,633(49.98 \%)$. 


\section{STATUS OF WOMEN IN INDIA}

Woman status in the Indian society has been through many ups and down in ancient to modern era. While discussing about the status of women, Kumari opines that in ancient India, women occupied a very important position, in fact a superior position to men. In Vedic times women and men were equal as far as education and religion was concerned. Women participated in the public sacrifices alongside men. The Haritasmriti mentions a class of women called brahmavadinis who remained unmarried and spent their lives in study and ritual. There were also many noteworthy women scholars of the past such as kathi, kalapi, and Bahvici. 1

In Medieval period India witnessed many social practices which were anti-women, such as sati, child marriage, and restrictions on widow marriage, became a part of social life. In spite of these anti- women elements, some women excelled in the fields of politics, literature, education and religion. *

During British rule in India, Biswas says it was the ruling East India Company that First hit the conservative Indian Society in the 18th century. 2 Women' education started in 1818 with the set up of a girl's school with 14 students in Chinasura by Robert May.

European scholars observed in the 19th century Hindu women are virtuous than other women. They tried to improve the status of women by raising their voice against women exploitation. Even the Indian social reformers worked hard to bring changes among women conditions.

In Independent India we can see the participation of women in all activities such as education, politics, media, art and culture, service sectors, science and technology, etc. Women in India have been in the Process of transformation in past few decades. Though women are nearly half of the total population but their representation in public life is very low. Women bear the major load of the household work. Her primary role is often viewed by the society as housewife. The plight of women in India ranges from domestic disparity to societal oppression. In most of the areas in India, a strong cultural bias favors sons over daughters. Female children frequently suffer neglect in terms of health care and education. Studies reveal that boys receive health care more often than girls, and the average amount spent on treatment was also significantly higher for boys. Subordination of women in society acts a structural constraint to their participation in political activities.

On the other hand today's India offers a lot of opportunities to women, so that women can have a voice in everyday life, the business world as well as in political life. Nevertheless India is still a male dominated society, where women are often seen as subordinate and inferior to men.

Ahuja opines that the status of women in India has changed a lot from early 1950s onwards. Both structural and cultural changes have not only provided equality of opportunities to women in education, employment and political participation, but have also reduced the exploitation of women, and oriented women to develop their own organizations which can take keen interest in their problems. ${ }^{3}$

The Constitution of India guarantees to all Indian women equality (Article 14). There also several commissions in the centre and state governments to study the causes of low status and problems of women and to safeguard their rights in various aspects. Ahuja consider that Indian women today are still not economically emancipated from man. In social, psychological and moral dimension also, her situation is not identical with that of man.

Today modern woman is so deft and self-sufficient that she can be easily called a superwoman, juggling many fronts single handedly. Women are now fiercely ambitious and are proving their metal not only on the home front, but also in their respective professions. Women in Indian are coming up in all spheres of life. They are joining the universities and colleges in large numbers. They are entering into all kinds of professions like engineering, medicine, politics, teaching, etc. A nation's progress and prosperity can be judged by the way it treats its women folk. There is a slow and steady awareness regarding giving the women their dues, and not mistreating them, seeing them as objects of possession. Despite progress, the very fact that women, along with being achievers, also are expected to fulfill their roles as wives or mothers, prioritizing home against anything else. This point of view hasn't changed much. There is still a large section of women who are uneducated, and married off before the age of 18.

Though women are nearly half of the total population but their representation in public life is very low. Women bear the major load of the household work. Her primary role is often viewed by the society as housewife. The plight of women in India ranges from domestic disparity to societal oppression. In most of the areas in India, a strong cultural bias favors sons over daughters. Female children frequently suffer neglect in terms of health care and education. Studies reveal that boys receive health care more often than girls, and the average amount spent on treatment was also significantly higher for boys. Subordination of women in society acts a structural constraint to their participation in political activities.

On the other hand today's India offers a lot of opportunities to women, so that women can have a voice in everyday life, the business world as well as in political life. Nevertheless India is still a male dominated society, where women are often seen as subordinate and inferior to men.

The Indian constitution grants women equal rights to men, but strong patriarchal traditions persist in many different societal parts, with women's lives shaped by customs that are centuries old. Hence, in these strata daughters are often regarded as a liability, and conditioned to believe that they are inferior and subordinate to men, whereas sons might be idolized and celebrated.

There are a couple of reasons, why men might be regarded an asset for a family among Hindus: 
- $\quad$ Considered capable of earning money

- Carry on the family line

- $\quad$ Able to provide for their aging parents

- $\quad$ Bring a wife (and with this a capable domestic helper) into the family

- Play an important role in death rituals in Hindu religion, which ensure, that the soul is released from the body and can go to heaven.

On the other hand, there are a couple of reasons why women might be regarded more of a liability for a family:

- Not considered capable of earning money

- Seen as economically and emotionally dependent on men

- While they help with domestic duties during childhood and adolescence, they go to live with their husband's family after marriage, which means less help in the household of their originating family, and most importantly loss of money due to the dowry tradition.

This might explain why the birth of a daughter may not always be perceived as equally blissful as the birth of a son, and why "May you be blessed with a hundred sons" is a common Hindu wedding blessing.

These kind of attitudes and believes creates imbalance in sex ratio that is females for thousand males. India is one of the few countries where males outnumber females. (ref. No. 1)

When we analyze sex ratio of India in 2014, it is 940 females for 1000 males; sex ratio in 2001 was 933 . This is mainly because of the female feticide and infanticide. The main reason of parents committing female feticide and infanticide is the fear of paying dowry in the marriage of their daughter. The reason behind increasing numbers of incidents of feticides and infanticides is lack of education among women. Indian Literacy rate itself shows the lack of education of women.

Total literacy rate is 74.04 of which male literacy rate is 82.14 where as female literacy rate is 65.46 and the gender gap is 16.68. This shows the lack of education among Indian women. An educated woman is able to meet the modern and advanced requirements of family such as vaccination of children and hygienic environment in the house, empowerment of women etc. It has been witnessed that there is a need of increasing awareness about empowerment of women so that measures such as social economic and political and broader access to fundamental human rights and improvement in nutrition, basic health and education.

\section{CONCLUSION}

Social transformation is an accumulative and continuous process. Women in India have been through social transformation since many decades. Indian women enjoyed liberty and choice of selection of partner, later period was not so good for women, status of women deteriorated. It was only after independence that women got their rights partially. So, it can be said that status of women has considerably improved. Because of which we find women in all sort of fields, giving tough competition to men and proving their skill and potential. The present paper is a review paper, highlighting various stages of social transformation among Indian women. And also analyzes different aspects of social transformation.

\section{REFERENCES}

1. Kumari Madhu,(2011). Women Empowerment And Social Change, Random Publications, New Delhi

2. Biswas (Bhawmik), (2010). Manjari, the Status Of Women In India: From Antiquity To Modernity, Abhijeet Publication, New Delhi, Pg. 75.

3. Ahuja Ram,(2013). Indian Society in Transition, Rawat Publication, Delhi.

4. Sharma.K.H, (2008). Indian Social Structure And Change, Rawat Publications, Jaipur.

5. Chandra, Suresh,(2011). Social Change In Modern India, Jnanda Prakashan, New Delhi, Pg No.224.

6. Cohen, Percy. S,(1968). Modern Social Theory, Heineman Educational Books, London.

7. Sharma.K.H,(2008). Indian Social Structure and Change, Rawat Publications, Jaipur.

8. Atal Yogesh,(2011). Changing Indian Society, Rawat Publishers, Jaipur.

9. Singh, Kamlesh,(2008). Social Change in Modern India, Navjang Publishers and distributors, New Delhi, Pg No 93.

10. Syed. $\mathrm{M} \mathrm{H}$,(2007). Social Change in India, Anmol Publications pvt Itd, New Delhi.

11. Geetanjali,(2011). Social Change in Modern society, Centrum press, New Delhi, Pg.144.

12. Chaudhary Vishwamitra prasand,(2011). Society in India, ABD Publishers, Jaipur,pg. No.66 \& 68.

13. Kansal.jairam,(2004). Sociology of Social Change, Dominant Publications and distributors. New Delhi, Pg 181. 


\section{ISSN 2321-1091}

14. Dhak. Biplab,(2009). Gender Inequality In Health In India: Life Course And Neighbourhood Dimension, University Of Mysore, (Unpublished Thesis), Pg 9.

15. Dr MIH. Farooqi,(2011). Status of Muslim Women in Islamic Societies-Past and Present, www.countercurrents.org. (e-journal).

16. Tanima. Banerjee,(2012). Here's How The Status Of Women Has Changed In India (Since 1950-Till Date), www.youthkiawaaz.com.

17. http://www.saarthakindia.org/womens situation India.html

18. http://www.worldometers.info/world-population/\#religions

19. http://www.sociologydiscussion.com

20. http://censusindia.gov.in/

\section{Author' biography with Photo}

Nazhath Sara presently a research scholar in department of studies in sociology, University of Mysore and did her Master of Arts at the University of Mysore and for her credit she is a qualified UGC- NET (National Eligibility test) and has three years experience in Lecturing. 